\title{
Frankie Goes to Vilnius
}

INGA UNTIKS

\section{REPLACING PUBLIC ART}

After Lithuania had declared independence from the Soviet Union, the city-space of Vilnius was altered by the removal of numerous busts and statues of Lenin, Marx and regional disciples, presented in the Socialist Realist style, that had stood beside the effigies of longdead Lithuanian poets, artists and heroes. The empty plinths left by their departure appeared as a supremely public expression of the uncertain future of the new Lithuanian republic. Throughout the early 1990s in Riga, the capital city of Latvia, the public image of the city became a hotly contested topic of debate in the mass media who presented the tensions as an example of the increasingly strained relations between the new nationalist government, newly developed interest groups and public opinion, all of which desired an imposing influence over the future of the recently independent republic. In Lithuania, however, these concerns were played out in the local imagination in a less political fashion as the boundaries between civic action and artistic concerns have traditionally been of a more fluid nature. While their Latvian and Estonian neighbors were endlessly debating the issue of the 'definitive' image that would represent the future of the newly independent nations, in Lithuania a group of artists in Vilnius created a symbol, almost accidentally, that would not only provide a definitive statement of the uncertain future of Lithuania but one that would distinctively declare the end the end of communism and demonstrate their newly found freedom: a bust of the American folk-rock musician, Frank Zappa.

The choice of Zappa is perhaps not as absurd as it would appear at first glance, despite the fact that Zappa never once crossed the borders into any of the three small Baltic nations before his death in 1993. When placed in the context of the cultural climate of late socialism, Zappa, as an anti-establishment figure who gained notoriety during the 1960s civil movements in America, had become a cult figure throughout much of Eastern and Central Europe. The history and influence of American rock music in late socialist culture and the early 
years of independence is well-documented and figures directly in the imagination of many artists during the transitional period of the late 1980s and early 1990s.[1] The apotheosis of American commodities and culture was rampant in the Baltics as well as the rest of post-socialist Europe, and cultural freedom and expression became an important indicator of social change. But as is typical of this phenomenon throughout post-socialist Europe, the appropriated images, actions, attitudes and lifestyles that had been transported from a very different social and historical culture often intersected bizarrely with local culture.

In the cultural climate of the late 1980s, irony and kitsch were often employed in response to the widespread propaganda of a decaying communist regime with its overtly serious and political public displays, the desire for non-traditional symbols and public statements continued therefore making the eccentric Zappa an appealing, if humorous representation of the current generation. A copper bust of the American legend was erected in 1993, the year of Zappa's death, and stands on a 4.2 meter high steel plinth in a peaceful park in the center of Vilnius a mere block away from one of the city's busiest shopping districts. Zappa's image, taken from the latter years of his life, carries a somber tone, as the pony-tailed figure presents an overtly serious expression, not fully unlike those depicted by the past leaders of socialism who had adorned the streets of Vilnius. In what follows I explore the official and untold stories of this statue as well as the significance of its location.

\section{TESTING THE LIMITS: THE OFFICIAL STORY}

In 1993, artist and photographer Saulius Paukstys, thirty-seven years old at the time, was president of the Lithuanian branch of the Frank Zappa Fan Club. After some discussion with other members of the group, he presented to the Vilnius city council a proposal for the erection of a statue of Frank Zappa outside the Vilnius Academy of Art that was supported by over three hundred signatures of artists, writers and even a few of the younger members of the Lithuanian parliament. Support for this unusual project was particularly strong among the creative professionals living in the nearby bohemian district of Uzupis, which had long carried a reputation for its absurd actions.

Government officials dealing with the request were naturally taken aback at first by this seemingly absurd proposal, yet after some persuasion, the necessary paperwork was passed with the sole clause being that all funding for the project was to be independently 
raised.[2] However, despite official approval, the project ran into several other snags as the conservative and bureaucratic city administration, which included a significant number of teachers from the Vilnius Academy of Art, was outraged at the possibility of Frank Zappa adorning the entrance to their institution. The nature of this outrage ranged from the fear of corrupting the innocent minds of students attending the institution, to the threat of bringing public shame upon the school that would result in a loss of much-needed funding.

Rumors quickly began to circulate throughout Vilnius with the intent of preventing the erection of the statue. Early claims stated that Zappa had been a homosexual and was therefore an inappropriate choice to represent the city and the institution. These were followed by allegations that communists were behind the commissioning of the statue, which was reinforced in the public imagination by Zappa's leftist lyrics and the fact that the artist donating the bust had worked as a sculptor in the Soviet regime. As a result of the opposition from the art academy and other conservative power-players, new sites were proposed and subsequently rejected. One was thought to be too close to a statue of a respected Lithuanian nationalist writer, where the company of Zappa was considered disrespectful. Another location not far from the Catholic Cathedral was also deemed unsuitable as Pope John II had recently visited Lithuania and the presence of Zappa was thought to potentially aggravate the increasing influence of the Catholic Church in Lithuania. In the end, a leafy park near a student hospital was agreed upon as the most suitable choice.

The unveiling ceremony organized by the Frank Zappa Fan Club was an event that Zappa himself would have undoubtedly enjoyed. Speeches and toasts were given to Zappa and Konstantinas Bogdanas, the seventy year-old sculptor who created the piece, accompanied by unusual renditions of Frank Zappa songs performed by a military band. Czech President Vaclav Havel was invited to the ceremony, and a local radio station broadcast the event live, followed by an extended Zappa-only program which included inspirational snippets from Zappa's personal writings and philosophy - translated into Lithuanian, of course.

For many the Zappa project symbolized a chance for Lithuania to distance itself from Russia while publicly declaring its place in Western culture and politics, a fact that to some extent explains the widespread public support. In the popular media, the erection of the Zappa statue was seen to be a confrontation with the fledgling democratic movement in Lithuania - a testing of the true limits of censorship and freedom of speech. However, these lofty aspirations were 
only a later development of a project which had begun quite accidentally.

\section{THE UNTOLD STORY}

In the early 1990s, a dedicated group of Zappa fans gathered regularly in the Uzupis area of Vilnius to swap Frank Zappa records and discuss the American culture that had been so determinedly suppressed under communist rule. The recent collapse of the Soviet Union opened the doors to previously inaccessible aspects of American culture, including Frank Zappa albums, which had been greatly coveted during the late socialist period. At the time, Zappa himself was all but unknown in the hearts and minds of Lithuania's three million citizens, but thanks to the actions of the artists of the Frank Zappa Fan Club, he quickly became a central symbol of Lithuanian independence.

Together with other artists, Paukstys created two bogus Zappa exhibitions at one of the numerous new art galleries in the rapidly gentrifying Uzupis area. The first exhibition featured letters purportedly written by Zappa himself to his Lithuanian admirers, and widespread public reaction and support for the exhibition, in part supported by the current vogue in American culture, inspired a second exhibition. "Memorial Objects of Frank Zappa" followed, displaying such bric-a-brac as clocks, knives, pens and items of clothing claimed to have been previously owned by Zappa. In truth, none of the items featured had ever travelled further than Paukstys's apartment.

These 'fictional' (some now say 'experimental') exhibitions were a massive hit with the Lithuanian public, far more so than other contemporary art displays. When questioned by local journalists about how the exhibitions came about, Paukstys fabricated a widely published story about his fictional brush with Zappa while on vacation in California. However a few years later, those involved with the organization of the exhibitions came clean, admitting that none of them had ever met Zappa, let alone been granted a private interview or received articles for the exhibitions. Vytautas Kernagis, a respected Lithuanian musician involved with the projects, explains how this phenomenon could have possibly taken hold of the city:

We never saw Zappa, but nobody ever saw God, and they still go to church. Lithuania is a nation of mythology, legends and fairytales. Everything is mystified. People believe really quickly, and one of the myths is that independence is good for everyone, with no exceptions. That's why, in such an environment, the Zappa seeds were so successfully planted.[3] 
The euphoria and optimism which followed the almost unthinkable collapse of the Soviet Union led many to believe that just about anything was possible. As a sense of disillusionment took root after the early uncertain transitional period, and after decades of lies and manipulations, people just wanted to believe. The sense of uncritical optimism that characterized much of the Lithuanian mentality during this time cleared a path for potential manipulation. The experience of the Zappa exhibitions proved the case for the necessity of critical analysis and public discussion that many artists felt to be lacking in the mentality of the early 1990s and spurred on a second wave of civil action in the form of an independence movement in the decaying Vilnius neighborhood of Uzupis.

\section{ZAPPA - PATRON SAINT OF UZUPIS}

For hundreds of years, Uzupis had been the relatively isolated home of mostly Russian and Jewish residents who had remained cut off from the Old Town until two bridges were built over the river in the sixteenth century. The natural beauty of the area and proximity to the center of town allowed Uzupis to develop as a desirable neighborhood for wealthy craftsmen and even some nobility. By the end of the two World Wars, however, the area had lost much of its acquired wealth and respectability as most of its population disappeared through emigration or extermination. The area was populated again soon after the war by poor laborers, under whose watch the neighborhood fell into neglect and decay. Until recently, the area was considered to be the most criminal part of the city, which contrasted starkly with the relative progress of the surrounding new Soviet-style areas.

The loosening of restrictions on movement, which occurred during the late socialist period in Lithuania, resulted in a small exodus from the tall Soviet apartment-blocks to Uzupis of artists, writers and other creative professionals in search of cheap property and adequate spacing for their endeavors. The slow process of gentrifying the area and the artistic life of this small enclave in the center of Vilnius adequately depicts the early grassroots efforts of a community in the middle of socio-political transition. Since 1991, countless galleries, cafes and studios have been built and renovated to the highest standards, only to be quickly abandoned due to the difficult economic circumstances plaguing the country and the lack of government support in administrative matters such as permits and taxation.

The eccentric population and the emerging spirit of the times created a distinctive community atmosphere, which is often compared to 
the Montmartre commune in Paris in the early 1800s - except with Frank Zappa as its patron saint. Despite local efforts, the area suffered continual neglect by the city council in such basic matters as adequate electricity and waste disposal, inspiring local artists to take civil action. As Paukstys states, "The spirit of Zappa made us see that independence from Moscow was not enough and persuaded us to declare independence from the rest of Vilnius." On April $1^{\text {st }}, 1993$, the Uzupio Republika, the Independent Republic of Uzupis, was established.

Today, the Republic of Uzupis is officially independent one day a year: April Fool's Day. Yet throughout the year the dedicated Uzupian council continues their work. There is a president, Romas Lileikis, a prime minister, a Ministry of Foreign Affairs, a functioning customs office, an embassy in Moscow and a local currency that occasionally circulates. As well, they have an official Uzupian Coat of Arms, four official flags (one for each season) and their own slogan, "Don't win. Don't defend. Don't give up," echoing the spirit of some early Fluxus projects which have found a significant degree of popularity in the neighborhood and the nation. For those who dare violate the unusual constitution of Uzupis, which claims such bizarre articles as "A man has the right to live near the river, and the river has the right to flow near a man," there is an army of seventeen to defend its existence. There is even an extensive calendar of holidays and traditions, a few of which coincide with Lithuanian national holidays and some of which are absurdly Uzupian.

Citizenship to the Uzupian republic is not merely limited to its 7,000 residents but also includes those who share its spirit and traditions no matter where in the world they live. Thus far, there are seventy ambassadors to Uzupis who have taken up the ritual of being presented with a hat and a whistle, including Jonas Mekas, the Lithuanian film director who lives in New York City, Arturas Zuokas, a former mayor of Vilnius, and the Dalai Lama. The area was given a further boost of notoriety after the first documentary film about Uzupis Ten Minutes Before the Flight of Icarus, directed by Uzupis resident Arunas Matelis, was shown at film festivals around the world and caught the interest of Werner Herzog.

The optimism of the area and its community spirit is in stark contrast with much of the rest of post-socialist Vilnius, which is often plagued by disillusionment and apathy. As President Lileikis explains,

We're trying to energize a community by asserting our independence. It's very different from the independence gained in '91, but we're trying to 
foster the same community spirit so that people can make things happen for themselves. That's a trait they lost through seventy years of oppression.[4]

The vision for Uzupis was to create a dynamic community atmosphere that was at once socially and politically critical, while retaining a sense of creativity and absurdity. Yet its existence also indicates an important social phenomenon of artists leading the way towards alternative modes of thinking and existence. The desire for change in Uzupis, as well as the Frank Zappa statue, were taken to the most basic grassroots level in order to circumvent the sluggish changes in the newly independent government and institutions. In a city where art is undoubtedly political, these projects signify the potential of artistic action to directly affect social and political change.

\section{NOTES}

[1]See Diena and Latvijas Atkarigas Laikrakstis throughout 1991 for further details of this debate.

[2]According to an interview with Paukstys in a Lithuanian newspaper, city government officials queried the relevance of Frank Zappa to Lithuania. After a third party convinced an official that Zappa had 'Jewish features' (during a time where appropriate treatment of Jewish history was important to the public image of Lithuania), city officials gave their consent.

[3]Vytautas Kernagis in interview with Kate Connolly in Rolling Stone magazine, March 29, 2002.

[4]Romas Lileikis in interview with Kate Connolly in Rolling Stone magazine, March 29, 2002. 